\title{
Increased ability to arrange two tier multiple choice questions
}

\author{
Yuni Pantiwati ${ }^{a, 1,}{ }^{,}$, Nurul Mahmudati ${ }^{a, 2}$ \\ ${ }^{a}$ Faculty of Teacher Training and Education, Universitas Muhammadiyah Malang, Jl. Raya Tlogomas No.246, Malang and 65144, Indonesia \\ ${ }^{1}$ yuni_pantiwati@yahoo.co.id *; 2 nurulmahmudati1@gmail.com \\ *Corresponding author
}

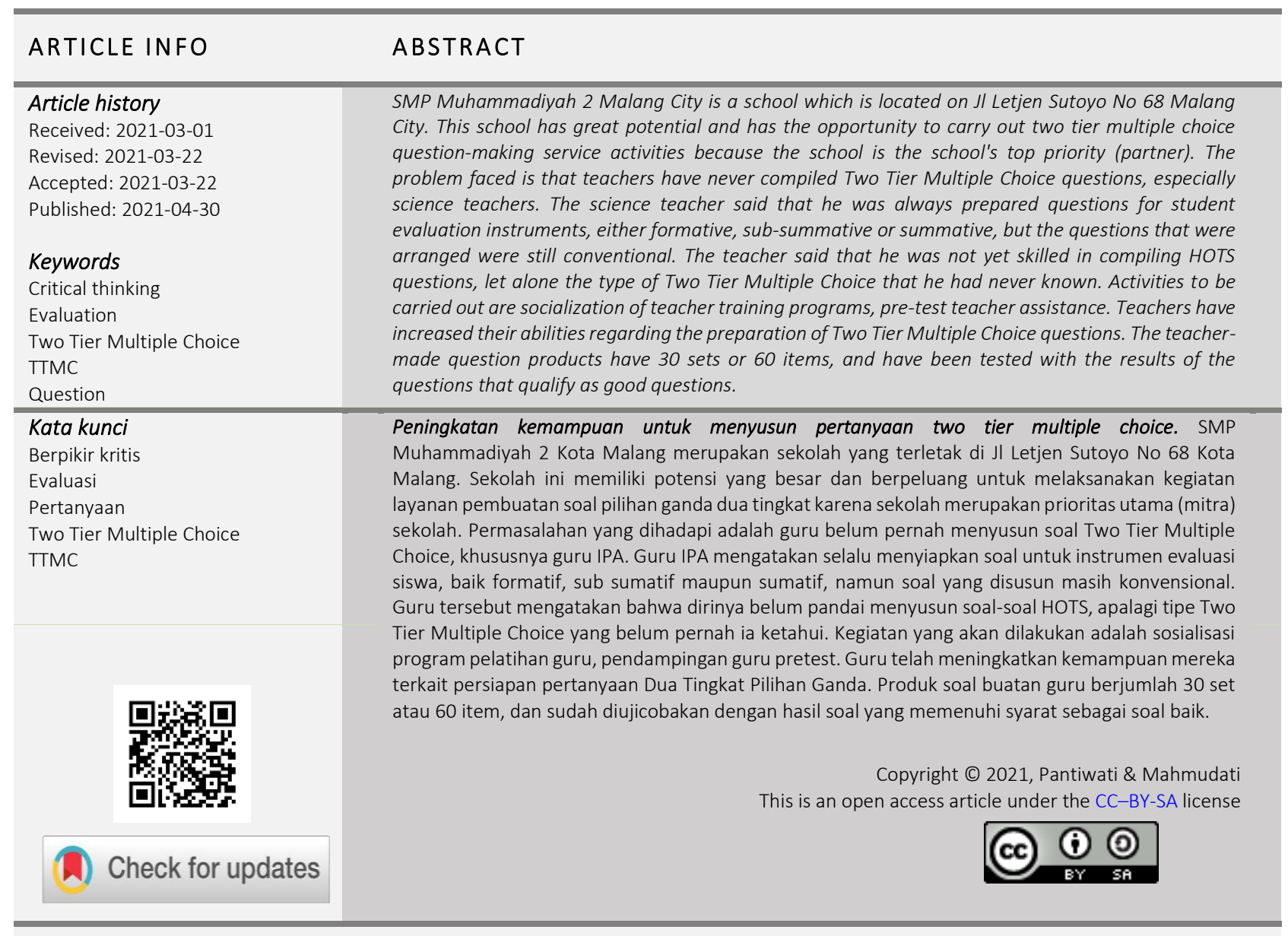

How to cite: Pantiwati, Y., \& Mahmudati, N. (2021). Increased ability to arrange two tier multiple choice question. Journal of Community Service and Empowerment, 2(1), 21-27. https://doi.org/10.22219/jcse.v2i1.15855

\section{PENDAHULUAN}

SMP Muhammadiyah 2 Kota Malang terletak di Jl Letjen Sutoyo No 68 Kota Malang. Sekolah ini menjadi sangat berpotensi dan berpeluang untuk dilakukan kegiatan pengabdian penyusunan soal Two Tier Multiple Choice (TTMC) dikarenakan di sekolah tersebut yang menjadi prioritas utama sekolah (mitra). Permasalahannya adalah guru belum pernah menyusun soal tipe tersebut diatas khususnya guru IPA. TTMC didefinisikan sebagai instrument tes yang terdiri dari dua tingkat, yaitu tangkat pertama terdiri atas pertanyaan dan tingkat kedua pilihan alasan yang mengacu pada tingkat pertama (Noprianti, 2017). Para Guru menyatakan belum pernah mempraktekkan instrument tersebut dan belum terampil menyusun soal berbasis berpikir tingkat tinggi atau Higher Order Thinking Skills (HOTS). Potensi yang lain adalah kepala sekolah beserta semua anggota sekolah mendukung adanya kegiatan program pengabdian terkait dengan penyususnan soal TTMC, selain itu guru bersemangat untuk mengikuti kegiatan pendampingan tersebut merupakan hal yang sangat penting ada nya kegiatan pendampingan ini. 
Keterampilan berpikir tingkat tinggi dapat diukur dengan menggunakan instrument dari berbagai tipe penilaian seperti, konstruksi jawaban singkat, konstruksi jawaban panjang, dan modified multiple choice seperti yang telah dilakukan oleh Ramirez dan Ganaden (2008). Modifikasi multiple choice salah satunya adalah bentuk TTMC question atau pilihan ganda bertingkat yang dapat digunakan untuk mengukur keterampilan berpikir tingkat tinggi (Mufida Nofiana, Sajidan, 2016). Desain instrumen pilihan ganda dua tingkat adalah serangkaian item yang memberikan stimulus terhadap siswa (Sholihah, Sarwanto, \& Aminah, 2020). Instrumen penilaian pilihan ganda bertingkat banyak digunakan dalam pendidikan sains sebagai metode yang efektif untuk mengevaluasi pemahaman siswa (Xiao, Han, Koenig, Xiong, \& Bao, 2018). Lapis kedua bertujuan untuk meningkatkan berpikir tingkat tinggi dan keterampilan penalaran sehingga ini bersifat memotivasi siswa. Pertanyaan pada tingkat pertama berkaitan dengan pernyataan pengetahuan sedangkan pertanyaan pada tingkat kedua merupakan pengujian tingkat berpikir lebih tinggi. Instrumen TTMC merupakan instrument yang bersifat lebih mudah walau dignakan untuk mengukur pemikiran siswa yang lebih tinggi dibandingkan dengan soal pilihan ganda tidak bertingkat. Instrumen ini dirasa cukup baik untuk untuk menganalisis kemampuan literasi sains atau peningkatan pemahaman tentang materi IPA. Melalui instrumen ini menjadikan siswa agar memberikan alasan atas jawaban mereka dan dengan demikian akan berisi konsepsi alternatif (Sesli \& Kara, 2012).

Berdasarkan hal tersebut maka kegiatan pengabdian pendampingan penyusunan soal TTMC di SMP Muhammadiyah 02 Kota Malang masih perlu dilakukan dengan tujuan, yaitu (1) Meningkatkan kemampuan guru dalam meningkatkan kemampuan pemahaman siswa melalui peningkatan keilmuan guru tentang variasi cara membuat soal tesberbasis HOTS; (2) Meningkatkan ketrampilan guru dalam membuat soal be rbasis TTMC untuk meningkatkan mutu pembelajaran IPA SMPKegiatan pengabdian ini untuk mendukung kemajuan proses pembelajaran di sekolah dengan memberikan bekal kompetensi penyusunan soal khususnya bersifat HOTS dengan baik dan benar; dan (3) Meningkatkan kompetensi professional guru dalam bidang ilmu yang diajarkan melalui kemampuanya membuat soal berbasis TTMC

Dan untuk lebih lanjut hasil kegiatan pengabdian ini adalah hasil pelaksanaan program penyusunan soal Two Tier Multiple Choice, dan diseminasi Bersama warga sekolah. Secara rinci target pengabdian diuraikan pada Tabel 1.

Tabel 1. Target pengabdian

\begin{tabular}{|c|c|c|}
\hline No & Kegiatan & Target \\
\hline 1 & $\begin{array}{l}\text { Pelaksanaan program penyusunan soal Two Tier } \\
\text { Multiple Choice }\end{array}$ & $\begin{array}{l}\text { Guru khususnya guru IPA mengikuti kegiatan program penyusunan } \\
\text { soal }\end{array}$ \\
\hline 2 & Terbentuknya tim penyusun soal IPA & Pembentukan tim penyusun soal IPA \\
\hline 3 & Tersusunnya soal Two Tier Multiple Choice & $\begin{array}{l}\text { Menghasilkan produk berupa soal Two Tier Multiple Choice berbasis } \\
\text { ujian nasional }\end{array}$ \\
\hline 4 & Diseminasi best practices & Dihasilkan diseminasi best practices pada kepala sekolah dan guru \\
\hline
\end{tabular}

\section{METODE}

Pelatihan dan pendampingan kepada 2 Guru IPA di sekolah SMP. Metode pendekatan yang digunakan dalam menyelesaikan permasalahan sekolah tersebut adalah berupa pelatihan dan pendampingan penyusunan soal Two Tier Multiple Choice serta dilakukannya diseminasi best practices dengan kepala sekolah dan guru. Secara lebih detail kegiatan pendekatan penyelesaian permasalahan ini dan partisipasi mitra dalam pelaksanaannya dapat dilihat pada Tabel 2.

Tabel 2. Kegiatan pelatihan dan pendampingan

\begin{tabular}{|c|c|c|}
\hline No & Kegiatan & Partisipasi \\
\hline 1 & $\begin{array}{l}\text { Pelatihan, pendampngan, penyampaian materi, dan } \\
\text { penyamaan persepsi }\end{array}$ & Diskusi dan sosialisasi \\
\hline 2 & $\begin{array}{l}\text { Diskusi, tanya jawab, dan bertukar pengalaman terkait } \\
\text { dengan: } \\
\text { Konsep Dasar penilaian HOTS dan Tersusunnya soal Two Tier } \\
\text { Multiple Choice } \\
\text { Pembentukan Tim soal IPA } \\
\text { Refleksi Keterlaksanaan Penilaian IPA } \\
\text { Sosialisasi Penyusunan soal Two Tier Multiple Choice materi } \\
\text { IPA berdas arkan Kisi-kisi soal ujian negara }\end{array}$ & Diskusi, pelatihan, workshop \\
\hline 3 & $\begin{array}{l}\text { Pendampingan Penyusunan soal } \\
\text { Dilanjutkan implementasi uji coba instrumen }\end{array}$ & Praktek, diskusi, evaluasi \\
\hline 4 & Diseminasi best practices dengan guru-guru lainnya & Praktek, diskusi, evaluasi \\
\hline 5 & Monev, dan persiapan artikel dan menyusun laporan & Diskusi, evaluasi \\
\hline
\end{tabular}

Selanjutnya kegiatan yang dilakukan dalam pelatihan yaitu Menyusun instrument Two Tier Multipe Choice yang sebelumnya dilakukan sosialisasi, pemahaman materi jenis instrument Two Tier Multiple Choice, pemahaman materi Biologi khususnya Biologi IPA. Kegiatan pelatihan secara rinci diuraikan pada Tabel 3. 
Tabel 3. Kegiatan pelatihan dan pendampingan

\begin{tabular}{|c|c|c|c|}
\hline Target Kegiatan & Kegiatan & Subyek \& Metode & $\begin{array}{c}\text { Instrumen pengukuran } \\
\text { ketercapaian }\end{array}$ \\
\hline $\begin{array}{l}\text { Pelaksanaan program } \\
\text { penyusunan Soal Two Tier } \\
\text { Multiple Choice }\end{array}$ & $\begin{array}{l}\text { Pengenalan program } \\
\text { Pelatihan dan } \\
\text { Pendampingan Pre-tes }\end{array}$ & $\begin{array}{l}\text { Warga sekolah: Ceramah, } \\
\text { Diskusi, Pendampingan }\end{array}$ & $\begin{array}{l}\text { Peningkatan pengetahuan guru IPA } \\
\text { tentang penyusunan soal HOTS IPA }\end{array}$ \\
\hline Pembentukan Tim Soal IPA & $\begin{array}{l}\text { Pembentukan Tim soal PA } \\
\text { Terpadu }\end{array}$ & $\begin{array}{l}\text { Kepala Sekolah dan guru: } \\
\text { musyawarah }\end{array}$ & Terbentuknya TIM Guru IPA Terpadu \\
\hline $\begin{array}{l}\text { Penyusunan Soal IPA } \\
\text { Terpadu dan implementasi } \\
\text { uji coba instrumen }\end{array}$ & $\begin{array}{lll}\text { Penyusunan } & \text { Soal } & \text { IPA } \\
\text { Terpadu } & & \end{array}$ & $\begin{array}{ll}\text { Warga sekolah: } & \text { Ceramah, } \\
\text { Diskusi, } & \text { pelatihan, } \\
\text { Pendampingan } & \end{array}$ & Terwujudnya Soal IPA Terpadu \\
\hline & Praktik baik kepada warga sek & & Terselenggaraannya Desiminasi \\
\hline
\end{tabular}

\section{HASIL DAN PEMBAHASAN}

Pelatihan dan pendampingan dilakukan kepada 2 guru IPA SMP selama 1 semester tahun akademik 2020/2021. Hasil pendampingan secara rinci diuraikan pada Tabel 4.

Tabel 4. Hasil dan ketercapaian pelatihan dan pendampingan

\begin{tabular}{|c|c|c|c|}
\hline Target Kegiatan & Kegiatan & Subyek \& Metode & Hasil \& ketercapaian \\
\hline $\begin{array}{l}\text { Pelaksanaan program } \\
\text { penyusunan Soal Two Tier } \\
\text { Multiple Choice }\end{array}$ & $\begin{array}{l}\text { Sosialisasi program } \\
\text { Pelatihan guru } \\
\text { Pendampingan guru } \\
\text { Pre-tes }\end{array}$ & $\begin{array}{l}\text { Warga sekolah: Ceramah, } \\
\text { Diskusi Pendampingan }\end{array}$ & $\begin{array}{l}\text { Terjadi Peningkatan pengetahuan } \\
\text { guru IPA tentang penyusunan soal } \\
\text { HOTS IPA dari rata-rata } 33 \text { menjadi } \\
85.5\end{array}$ \\
\hline Pembentukan Tim Soal IPA & $\begin{array}{l}\text { Pembentukan Tim soal PA } \\
\text { Terpadu }\end{array}$ & $\begin{array}{l}\text { Kepala Sekolah dan guru: } \\
\text { musyawarah }\end{array}$ & $\begin{array}{l}\text { Terbentuknya TIM Guru IPA Terpadu } \\
\text { dengan salah satu dari guru IPA } \\
\text { sebagai ketua dan satu orang yang } \\
\text { lain sebagai anggota, mengingat } \\
\text { hanya ada } 2 \text { guru IPA }\end{array}$ \\
\hline $\begin{array}{l}\text { Penyusunan } \\
\text { Terpadu }\end{array}$ & $\begin{array}{l}\text { Penyusunan } \\
\text { Terpadu }\end{array}$ & $\begin{array}{l}\text { Warga sekolah: Ceramah, } \\
\text { Diskusi, } \\
\text { Pendampingan }\end{array}$ & $\begin{array}{l}\text { Tersusunnya } 30 \text { set soal Two Tier } \\
\text { Multiple Choice IPA Terpadu, } \\
\text { sehingga ada } 60 \text { item }\end{array}$ \\
\hline Uji coba soal & Uji coba soal & Siswa SMP & $\begin{array}{l}\text { Instrumen yang telah diujicobakan } \\
\text { dan hasilnya baik }\end{array}$ \\
\hline \multicolumn{3}{|c|}{ Diseminasi best practices dengan Kepala sekolah, guru } & Desiminasi bersama warga sekolah \\
\hline
\end{tabular}

Berdasarkan resum hasil kegiatan pelatihan pada Tabel 4 menunjukkan bahwa untuk pengetahuan guru tentang Two Tier Multiple Choice mengalami peningkatan sekitar 60 point dari pre tes ke postes. Pengukuran pretest sebelum diberi kan sosialisasi tentang Two Tier Multiple Choice, kemudian guru diberikan pemahaman materinya. Selanjutnya diukur kembali dengan diberikan soal yang sama berupa multiple choice. Secara visual hasilnya seperti pada Gambar 1.

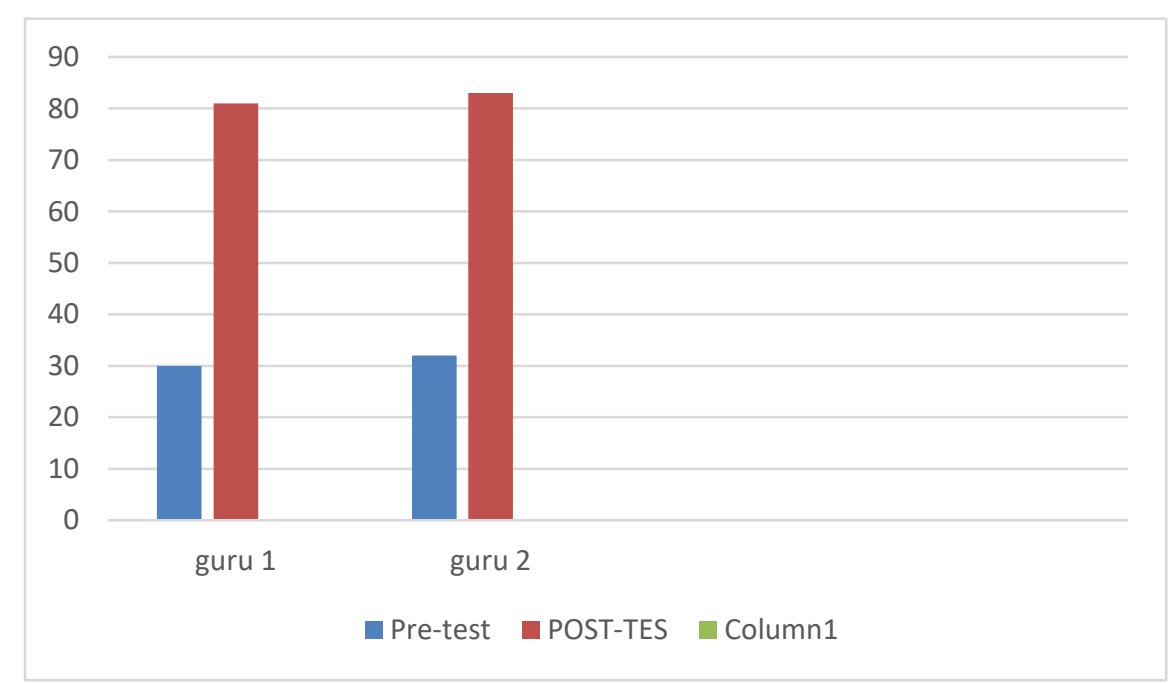

Gambar 1. Grafik pengetahuan guru

Peningkatan pengetahuan guru merupakan dampak dari pemberian materi tentang TTMC yang diberikan penjelasan secara lisan melaui ceramah dan tanya jawab. Hasil penelitian menunjukkan pengetahuan guru tentang TTMC yaitu tentang pengertian, tujuan, manfaat, karakteristik, sejarah, dan cara membuat instrument TTMC mengalami peningkatan 
(nilai pretest posttest dapat dilihat pada penjelasan di tabel 4.1 dan Grafik pada gambar 1. Pelatihan menggunakan metode ceramah dan pendampingan. Metode ceramah merupakan hubungan timbal balik antara pengajar dan peserta didik secara lisan. Hasil penelitian Raden Rizky Amaliah, Abdul Fadhil (2014) menunjukkan bahwa terjadi peningkatan hasil belajar ketika kegiatan pembelajaran menggunakan metode ceramah. Dalam implementasi metode ceramah dalam pembelajaran, tetap diselipkan tanya jawab dengan peserta didik agar suasana pembelajaran tetap hidup, target penyampaian materi terpenuhi. Sehingga terjadi peningkatan minat belajar peserta didik yang dirasa efektif walau menggunakan metode ceramah (Savira, Fatmawati, Rozin Z, \& Eko S, 2018).

Peserta pelatihan belajar menyusun instrument TTMC, namun sebelumnya terlebih dahulu peserta diberikan penguatan materi Biologi untuk SMP.

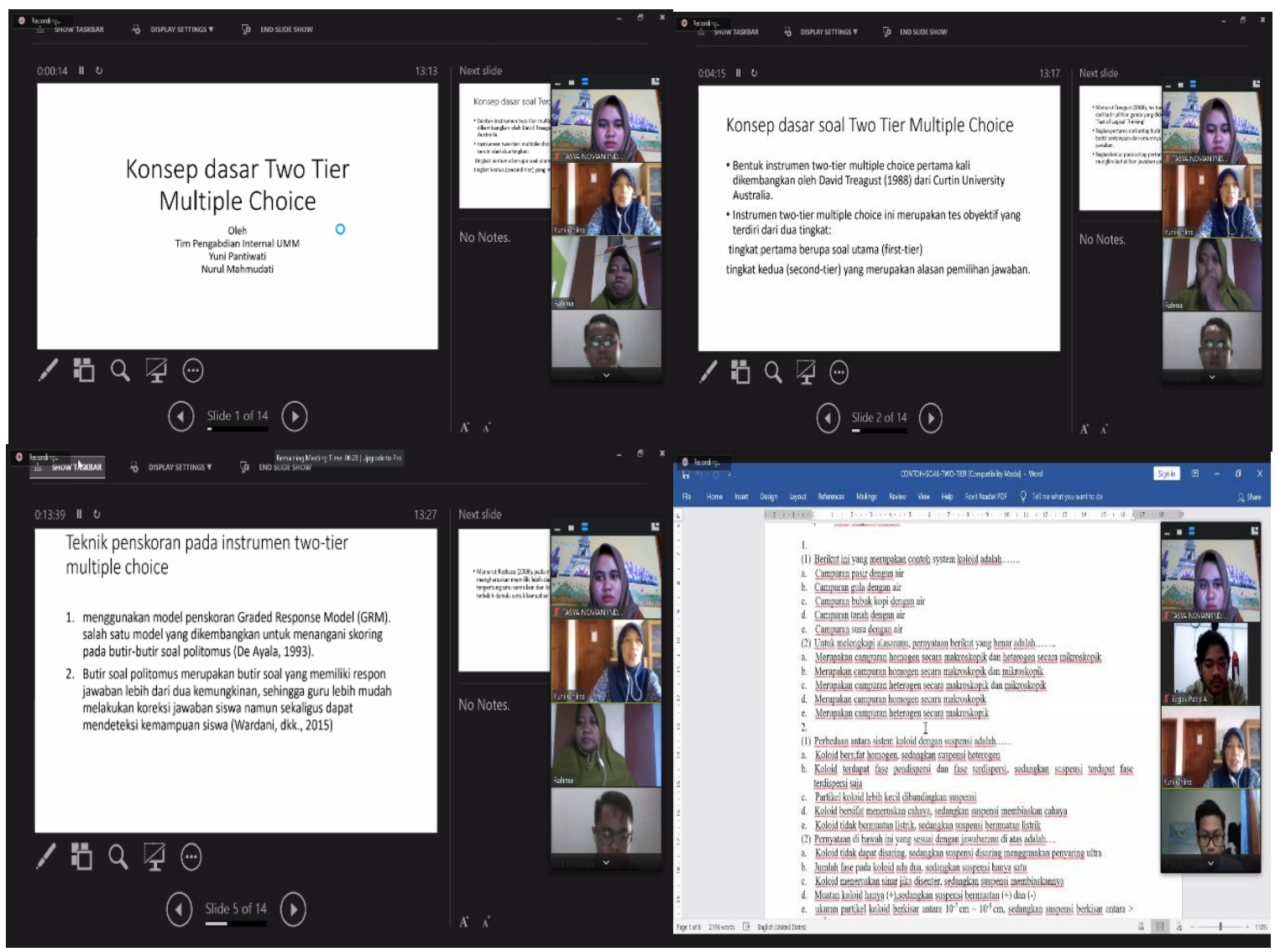

Gambar 2. Kegiatan pedampingan

Penjelasan lebih lanjut tentang cara menyusun soal TTMC melalui pelatihan menggunakan metode ceramah dan pendampingan. Ada 3 aspek utama yang perlu diperhatikan untuk mengembangkan Instrumen TTMC sebagai berikut : (a) konten ditentukan oleh identifikasi pernyataan pengetahuan konten proposisional dari topik yang akan diajarkan dan pengembangan peta konsep yang mengakomodasi pernyataan proposisional; (b) informasi tentang konsepsi siswa diperoleh dari sejauh mana literatur penelitian, jika tersedia, dan jika tidak tersedia dengan meminta siswa memberikan penjelasan tanggapan gratis atas jawaban mereka dan melakukan wawancara tidak terstruktur dengan siswa yang sebelumnya telah diajarkan isi / konsep; dan (c) pengembangan item diagnostik pilihan ganda dua tingkat (Adodo, 2013).

TTMC memiliki beberapa keunggulan selain sebagai alat ukur mengukur keterampilan proses sains, antara lain juga untuk mengukur pemahaman konsep peserta didik, dapat digunakan untuk mengukur keterampilan pengetahuan peserta didk juga digunakan meningkatkan pembelajaran dan keterampilan dalam berpikir (Sholihah et al., 2020). Teknik yang digunakan dalam membuat skor TTMC adalah Tidak menjawab (TJ) skor 0 atau kalau Jawaban salah- dan alasan juga salah (SS), Jawaban yang Salah- dan alasan benar (SB) skor 1, Jawaban yang benar- dan alasan salah (BS) skor 2, Jawaban benar-alasan benar (BB) skor 3. Melalui teknik persekoran diatas diharapkan mampu untuk menganalisis kemampuan siswa sekaligus sebagai tes diagnostik (Shidiq, Masykuri, \& H, 2014). Hasil pelatihan berupa soal TTMC dengan karakteristik seperti pada Tabel 5. 
Tabel 5. Karakteristik two tier multiple choice buatan guru

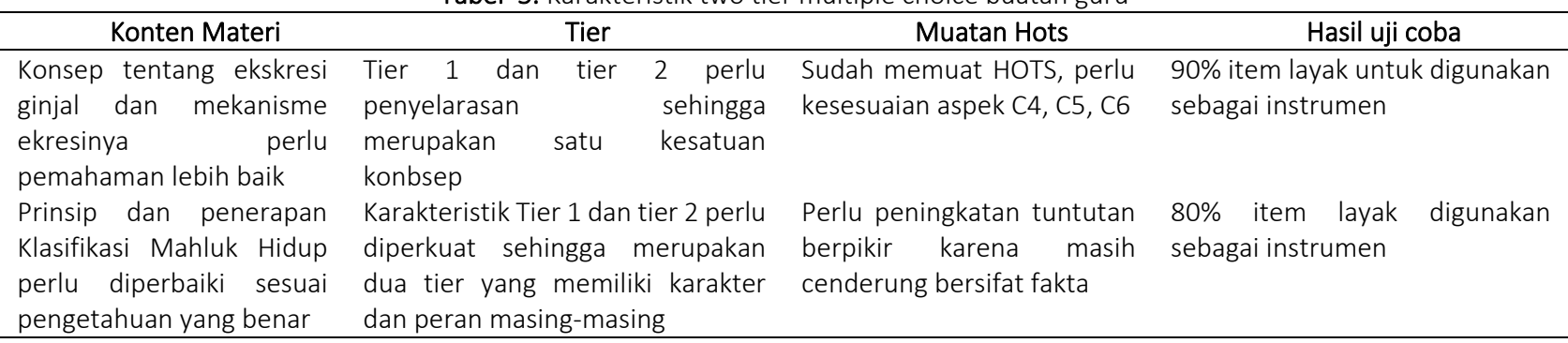

Melalui kegiatan pelatihan Guru sudah dapat menyusun soal TTMC, hanya perlu ditingkatkan agar soal yang dibuat menjadi lebih baik. Konsep tentang ekskresi ginjal perlu ditingkatkan kemampuan memahami. Pemahaman konsep merupakan suatu hal yang penting bagi seorang siswa. Ketika seorang siswa pemahaman konsepnya baik, maka siswa tersebut mampu untuk menjelaskan kembali materi apa yang sudah dipelajari berdasarkan pemahaman yang mereka miliki (Nahdi, Yonanda, \& Agustin, 2018). Selain itu, apabila memiliki pemahaman yang baik siswa akan bisa merasakan dampak pemahaman yang diterapkan dalam kehidupan siswa sehar-hari. Memahami suatu konsep merupakan salah satu tipe hasil belajar tingkat tinggi dalam pengetahuan. Contoh kemampuan menjelaskan menggunakan kalimat sendiri sebagai hasil dari memahami suatu bacaan atau yang telah didengarnya, memapuan m,encontohkan, atau memberi petunjuk terhadap implementasi sesuatu (Agustina, 2016). Sedangkan untuk kontens materi Klasifikasi mahluk hidup perlu kejelasan prinsip dan penerapan.

Produk soal buatan guru kemudian diuji cobakan di SMP kelas 8. Akbar dan Muhammad (2017) menyarankan diperlukan pemahaman dan kemampuan dalam penyusunan instrumen tes yang baik. Aat ukur dikategorikan sebagai instrument yang baik jika sudah memenuhi syarat, yaitu bersifat ekonomis, tidak membutuhkan biaya yang banyak, obyektif maksudnya mengukur apa adanya, reliabilitas yaitu dapat mengukur dengan hasil yang sama walau dipakai berulang-ulang, valid tentu menjadi syarat utama yaitu dapat mengukur yang seharusnya diukur, serta praktis memiliki sifat mudah digunakan. (Purwanti, 2014). Hasil yang diperoleh bahwa soal memenuhi syarat sebagai soal IPA Biologi untuk siswa kelas 8 SMP. Tahap terakhir yaitu mendesiminasikan hasil kegiatan kepada Kepala Sekolah, Wakil Kepala Sekolah, dan Guru di SMP Muhammadiyah 2 Kota Malang. Mendesiminasikan atau desiminasi merupakan salah satu proses menyebarluaskan hasil temuannya. Menurut Jamal dan Mardiharini (2016) ada berapa unsur penting dalam menentukan keberhasilan suatu proses, yaitu bersifat inovatif, aspek waktu atau proses, dan orang yang terlibat.

\section{KESIMPULAN}

Melalui kegiatan pendampingan penyusunan soal TTMC, Guru SMP 2 Muhammadiyah Malang mengalami peningkatan kemampuan tentang penyusunan soal Two Tier Multiple Choice. Produk soal buatan guru ada 30 set atau 60 butir soal, dan telah diujicobakan dengan hasil uji coba soal memenuhi syarat sebagai soal yang baik.

\section{UCAPAN TERIMA KASIH}

Terimakasih kepada pihak Universitas Muhammadiyah yang telah memfasilitasi sehingga kegiatan pengabdian kepada masyarakat ini dapat terlaksana.

\section{REFERENSI}

Adodo, S. O. (2013). Effects of Two-Tier Multiple Choice Diagnostic Assessment Items on Students' Learning Outcome in Basic Science Technology (BST). Academic Journal of Interdisciplinary Studies, 2(2), 201-210. https://doi.org/10.5901/ajis.2013.v2n2p201

Agustina, L. (2016). Upaya Meningkatkan Kemampuan Pemahaman Konsep dan Pemecahan Masalah Matematika Siswa SMP Negeri 4 Sipirok Kelas VII Melalui Pendekatan Matematika Realistik (PMR). EKSAKTA : Jurnal Penelitian Dan Pembelajaran MIPA, 1(1), 1-7. https://doi.org/http://dx.doi.org/10.31604/eksakta.v1i1.\%25p

Mufida Nofiana, Sajidan, dan P. (2016). Pengembangan Instrumen Evaluasi Higher Order Thinking Skills Pada Materi Kingdom Plantae. J. Pedagogi Hayati, 01(01), 46-53. Retrieved from http://id.portalgaruda.org/article.php?article=479414\&val=9781

Nahdi, D. S., Yonanda, D. A., \& Agustin, N. F. (2018). Upaya Meningkatkan Pemahaman Konsep Siswa Melalui Penerapan Metode Demonstrasi Pada Mata Pelajaran Ipa. Jurnal Cakrawala Pendas, 4(2), 9. https://doi.org/10.31949/jcp.v4i2.1050

Noprianti E dan Utami L, (2017). Penggunnaan Two Tier Multiple Choice Diagnostik Test disertai CRI untuk Menganalisi Miskonsepsi Siswa. Jurnal Tadris Kimia 2(2): 124-129

Purwanti, M. (2014). Analisis Butir Soal Ujian Akhir Mata Pelajaran Akuntansi Keuangan Menggunakan Microsoft Office 
Excel 2010. Jurnal Pendidikan Akuntansi Indonesia, 12(2). https://doi.org/10.21831/jpai.v12i2.2710

Raden Rizky Amaliah, Abdul Fadhil, S. N. (2014). Penerapan Metode Ceramah dan Diskusi dalam Meningkatkan Hasil Belajar PAI di SMA Negeri 44 Jakarta. Studi Al-Qur'an; Membangun Tradisi Berfikir Qur'an, 10(2), 119-131. Retrieved from http://journal.unj.ac.id/unj/index.php/jsq/article/view/4441

Savira, A. N., Fatmawati, R., Rozin Z, M., \& Eko S, M. (2018). Peningkatan Minat Belajar Siswa Dengan Menggunakan Metode Ceramah Interaktif. Journal Factor M, 1(1), 43-56. https://doi.org/10.30762/f_m.v1i1.963

Sesli, E., \& Kara, Y. (2012). Development and application of a two-tier multiple-choice diagnostic test for high school students' understanding of cell division and reproduction. Journal of Biological Education, 46(4), $214-225$. https://doi.org/10.1080/00219266.2012.688849

Shidiq, A. S., Masykuri, M., \& H, E. S. V. (2014). Pengembangan Instrumen Penilaian Two-Tier Multiple Choice Untuk Mengukur Keterampilan Berpikir Tingkat Tinggi (Higher Order Thinking Skills) Pada Materi Kelarutan Dan Hasil Kali Kelarutan Untuk Siswa Sma/Ma Kelas Xi. Jurnal Pendidikan Kimia, 3(4), 83-92. Retrieved from https://jurnal.fkip.uns.ac.id/index.php/kimia

Sholihah, N. A. A., Sarwanto, \& Aminah, N. S. (2020). Development of two-tier multiple choice instrument to measure science process skill. Journal of Physics: Conference Series, 1521(2). https://doi.org/10.1088/17426596/1521/2/022053

Xiao, Y., Han, J., Koenig, K., Xiong, J., \& Bao, L. (2018). Multilevel Rasch modeling of two-Tier multiple choice test: A case study using Lawson's classroom test of scientific reasoning. Physical Review Physics Education Research, 14(2), 20104. https://doi.org/10.1103/PhysRevPhysEducRes.14.020104 